\title{
An Environmentally Benign Approach for As (V) Absorption from Wastewater Using Untreated Coffee Grounds-Preliminary Results
}

\author{
Gnu Nam ${ }^{1} \mathbb{D}$, Min-Suk Kim $^{1}$, Namju Lee ${ }^{1}$, Young-Hoon Choi ${ }^{2}$ and Ji Whan Ahn ${ }^{1, *}$ \\ 1 Center for Carbon Mineralization, Korea Institute of Geoscience and Mineral Resources, \\ Daejeon 34132, Korea; gnunam@kigam.re.kr (G.N.); energy_7@naver.com (M.-S.K.); nj9468@nate.com (N.L.) \\ 2 Department of Advanced Materials Technology, Daesung MDI, Yeongwol 33058, Korea; \\ goodstart21c@naver.com \\ * Correspondence: ahnjw@kigam.re.kr; Tel.: +82-42-861-3990
}

Received: 13 September 2017; Accepted: 5 November 2017; Published: 7 November 2017

\begin{abstract}
Arsenic contamination of water is a worldwide issue due to its severe effects on the human body. Coffee grounds are a porous material with network structures, making it absorb other substances such as some gases or elements. In this research, renewable coffee wastes were used as an adsorbent to extract arsenic (As) from wastewater. In order to evaluate the usefulness of untreated coffee grounds, a series of preliminary tests for attachment of arsenic to coffee grounds were provided. The Brunauer-Emmett-Teller (BET) surface area and adsorption-desorption isotherms of an untreated coffee ground obtained from $\mathrm{N}_{2}$ gas adsorption were provided, and pore sizes was obtained using Barrett-Joyner-Halenda (BJH) method. The adsorption capacities of the coffee waste were verified through a series of experimental processes changing the conditions such as concentration of arsenic, initial amount of coffee grounds, and $\mathrm{pH}$. The maximum absorption concentration of $6.44 \mathrm{mg} / \mathrm{L}$ on $1 \mathrm{~g}$ of coffee grounds at $1.00 \mathrm{mM}$ of arsenic solution was observed. It was demonstrated that the modification by the cation species or pretreatment processes, such as calcination, will be necessary to enhance the absorption capacity for the extraction of arsenic.
\end{abstract}

Keywords: heavy metal; extraction; arsenic; coffee ground; BET

\section{Introduction}

Water contamination occurred from the industrialization and urbanization has posed large social and environmental problems [1-5]. Among various problems, the release of toxic heavy metals-such as lead $(\mathrm{Pb})$, arsenic $(\mathrm{As})$, or cadmium $(\mathrm{Cd})$-into the river or sea has been considered a worldwide issue due to their non-biodegradability and accumulation, threatening the aquatic life and human health [6-9]. Particularly, water pollution by arsenic presents severe problems for human health, including skin damage and cancer due to its good mobility in water-especially in India, Bangladesh, and Vietnam [6,10-12]. Therefore, the extraction of heavy metal elements from the wastewater has been important subject to many researchers and scientists until now. Various suggested methods to treat the heavy metal elements from the wastewater have been proposed-such as chemical precipitation, absorption, coagulation, ion exchange, and membrane filtration [13-20] — but no best method has not been proposed until now. Among those possible techniques, an adsorption method using the biomass such as coffee and algae has been considered as one of the promising methods for the removal of heavy metals from wastewater [21-25].

Coffee is one of the world's most popular beverages, and billions of tons of coffees are consumed, with increasing demand every year in many countries. However, approximately total $50 \%$ of coffee beans are disposed as spent coffee wastes and incinerated. During the incineration process, several 
harmful gases such as carbon dioxide and methane were discharged to the air, which results in environmental problems. In addition, the disposed coffee wastes contain moisture and diverse organic matter, which produces harmful viruses and emits bad smells. As one of various methods to manage spent coffee wastes, the use of coffee wastes as an absorbent has been explored as a potential candidate for the extraction of heavy metal elements from wastewater, since the coffee grounds possess many pores to capture the specific matters and contain several functional groups including the hydroxyl and amino groups on the surface of the coffee, which makes specific substances absorbed by a chemical interaction [26-28]. For example, Azouaou et al. demonstrated that the adsorption of cadmium was observed in aqueous solutions by using untreated coffee grounds [29]. In addition, lead and mercury from wastewater were removed using spent coffee bioelastomeric composite forms in a study by Fragouli et al. [30]. However, to the best of our knowledge, no study to remove arsenic from the wastewater by using untreated coffee grounds has been reported. Even though Prof. Valiyaveettil reported the extraction of arsenic from the water using spent coffee powder, chemical additives such as the bioadsorbent modified with polyethylenimine (PEI) and ferric ions were used to treat the wastewater [31].

In this research, our group first discussed the possibility of the removal of arsenic element from wastewater using untreated coffee grounds. A series of preliminary tests were conducted to eliminate the arsenic element from the wastewater, where the experimental results for the removal of the arsenic elements based on the different amount of coffee wastes and arsenic concentrations as well as different $\mathrm{pH}$ to find the optimum condition were provided. Furthermore, pore structure of coffee waste was characterized by adsorption-desorption isotherms.

\section{Materials and Methods}

\subsection{Sample Preparation and Adsorption Experiment}

The spent coffee grounds were collected directly from two local markets of two large coffee companies in South Korea and washed three times with distilled water to remove the impurity or residue, which was further dried with an oven at $100{ }^{\circ} \mathrm{C}$ for $24 \mathrm{~h}$ in order to create the same conditions of samples. The wastewater containing arsenic element was obtained using $\mathrm{HAsNa}_{2} \mathrm{O}_{4} \cdot 7 \mathrm{H}_{2} \mathrm{O}$, in which arsenic solutions with concentrations of $0.25,0.50$, and $1.00 \mathrm{mM}$ were prepared at $\mathrm{pH} 7.0$. A series of experimental investigations under different conditions such as the $\mathrm{pH}$, concentration of arsenic and amount of coffee waste were conducted. In order to evaluate the absorption capacity for arsenic using coffee wastes, $500 \mathrm{~mL}$ of different concentrations of arsenic wastewater ranging from $0.25 \mathrm{mM}$ to $1.00 \mathrm{mM}$ were prepared in $1 \mathrm{~L}$ of a constant-temperature water bath. After then the $25 \mathrm{~g}$ of coffee grounds were added to the wastewater with continuous stirring at $30^{\circ} \mathrm{C}$ for $1.5 \mathrm{~h}$. The products were filtered and washed with distilled water to remove the residues or excess reagents. The filtered coffee grounds were dried with an oven at $100{ }^{\circ} \mathrm{C}$ for $24 \mathrm{~h}$. In addition, a series of experimental investigations depending on the different amount of initial coffee grounds were conducted. The initial amounts of 25, 50, $100 \mathrm{~g}$ of coffee grounds were added into the wastewater with $0.50 \mathrm{mM}$ arsenic concentration, followed by the same experimental conditions. Furthermore, three $500 \mathrm{~mL}$ of $0.50 \mathrm{mM}$ arsenic solutions with 4.0, 7.0, and $10.0 \mathrm{pH}$ were prepared using $1.0 \mathrm{M} \mathrm{H}_{2} \mathrm{SO}_{4}$ for acidic and $1.0 \mathrm{M}$ $\mathrm{NaOH}$ for basic solutions. A measure of $1 \mathrm{~g}$ of coffee grounds and $0.50 \mathrm{mM}$ of arsenic solution with the same experimental conditions were used in those experiments.

\subsection{Characterization}

Total surface area $\left(S_{\mathrm{t}}\right)$, pore volume $\left(V_{\mathrm{p}}\right)$, and pore size $\left(R_{\mathrm{m}}\right)$ of the coffee waste were obtained from nitrogen adsorption-desorption isotherms at $77 \mathrm{~K}$ using an automatic Micromeritics ASAP-2420 volumetric sorption analyzer, in which Brunauer-Emmett-Teller (BET) model for $S_{t}$ and Barrett-Joyner-Halenda (BJH) method for $V_{\mathrm{p}}$ and $R_{\mathrm{m}}$ were used in this analysis. The samples were degassed for $0.5 \mathrm{~h}$ at $90{ }^{\circ} \mathrm{C}$ and $12 \mathrm{~h}$ at $100{ }^{\circ} \mathrm{C}$ to eliminate the impurities on the surface. No pressure 
variation at $1 \mathrm{~Pa}$ was observed during the degassing process. Nitrogen adsorption isotherms were measured over relative pressure $\left(P / P_{0}\right)$ ranging from $1 \times 10^{-3}$ to 0.976 . In addition, the adsorption pore size distribution was obtained using $\mathrm{BJH}$ method.

Inductive coupled plasma-optical emission spectroscopy (ICP-OES) was used to measure the quantitative concentration of arsenic ions from the water. Three replicates for each sample were performed to check the accuracy of data. Linear calibration curves with six points were obtained by using aqueous standard solutions. All residual values of each test were under $1.0 \%$.

\section{Results and Discussion}

\subsection{Structural Characteristics}

In order to evaluate the possibility as an adsorbent of an untreated coffee waste, total surface area $\left(S_{\mathrm{t}}\right)$, pore volume $\left(V_{\mathrm{p}}\right)$, and pore size $\left(R_{\mathrm{m}}\right)$ were measured using the BET and BJH methods. The resultant data were given in Table 1, which was compared with activated carbon and CMK-3 carbon, known as promising absorbents [32-34]. In the case of activated carbon and CMK-3, total surface area and medium pore radius were $1212 \mathrm{~m}^{2} / \mathrm{g}$ and $1508 \mathrm{~m}^{2} / \mathrm{g}$, and $3 \AA$ and $39 \AA$, showing the general characteristics of the good adsorption material. On the other hand, raw coffee waste contained relatively low values with surface area $\left(0.0047 \mathrm{~m}^{2} / \mathrm{g}\right)$ and pore volume $\left(0.000935 \mathrm{~cm}^{3} / \mathrm{g}\right)$. However, large medium pore radius was observed in the coffee grounds. Those values indicated that the coffee grounds had a low porosity structure, or were filled with other substances that were not eliminated. Therefore, pretreatment processes such as calcination will be necessary to enhance the adsorption property.

Table 1. Total surface area $\left(S_{\mathrm{t}}\right)$, pore volume $\left(V_{\mathrm{p}}\right)$, and medium pore size $\left(R_{\mathrm{m}}\right)$ of coffee waste from $A$ company and activated carbon.

\begin{tabular}{cccc}
\hline Adsorbent & Total Surface Area $\left(\mathrm{m}^{2} / \mathbf{g}\right)$ & Pore Volume $\left(\mathrm{cm}^{3} / \mathbf{g}\right)$ & Medium Pore Size (̊̊) \\
\hline Coffee waste & 0.047 & 0.000935 & $292.92-427.97$ \\
Activated carbon [33] & 1212 & 0.60 & 3 \\
CMK-3 [34] & 1508 & 0.86 & 39 \\
\hline
\end{tabular}

A plot for adsorption-desorption isotherms was illustrated in Figure 1. Based on the definition of IUPAC (International Union of Pure and Applied Chemistry), porous solid materials are divided into three classifications depending on the predominant pore sizes; (1) microporous material having the pore size under $2.0 \mathrm{~nm}$, (2) mesoporous material with the pore size between $2.0 \mathrm{~nm}$ and $50.0 \mathrm{~nm}$ and (3) macroporous material showing the pore size exceeding $50.0 \mathrm{~nm}$ [35]. According to IUPAC classification, a total six types of isotherms are determined depending on the pore size of the material [34]. The adsorption-desorption isotherms of the raw coffee waste belonged to the Type V, which is associated with the mesoporous structure. Furthermore, isotherms with Type V are classified with $\mathrm{H} 1, \mathrm{H} 2, \mathrm{H} 3$, and $\mathrm{H} 4$ according to the characteristics of the material. The isotherm of the coffee grounds does not show the limiting adsorption at high $P / P_{0}$, giving rise to $\mathrm{H} 3$, which is generally observed with aggregates with a plate-like particles.

The pore size distributions of coffee grounds were shown in Figure 2. The plot of pore size distribution displayed the mesoporous structure ranging from $5 \mathrm{~nm}$ to $20 \mathrm{~nm}$, which is in accordance with a result of isotherms. Therefore, untreated coffee wastes can be considered as a possible absorbent with various pore sizes. However, as mentioned above, due to its small surface area, the adsorption property will be enhanced through the pretreatment process such as a calcination. 


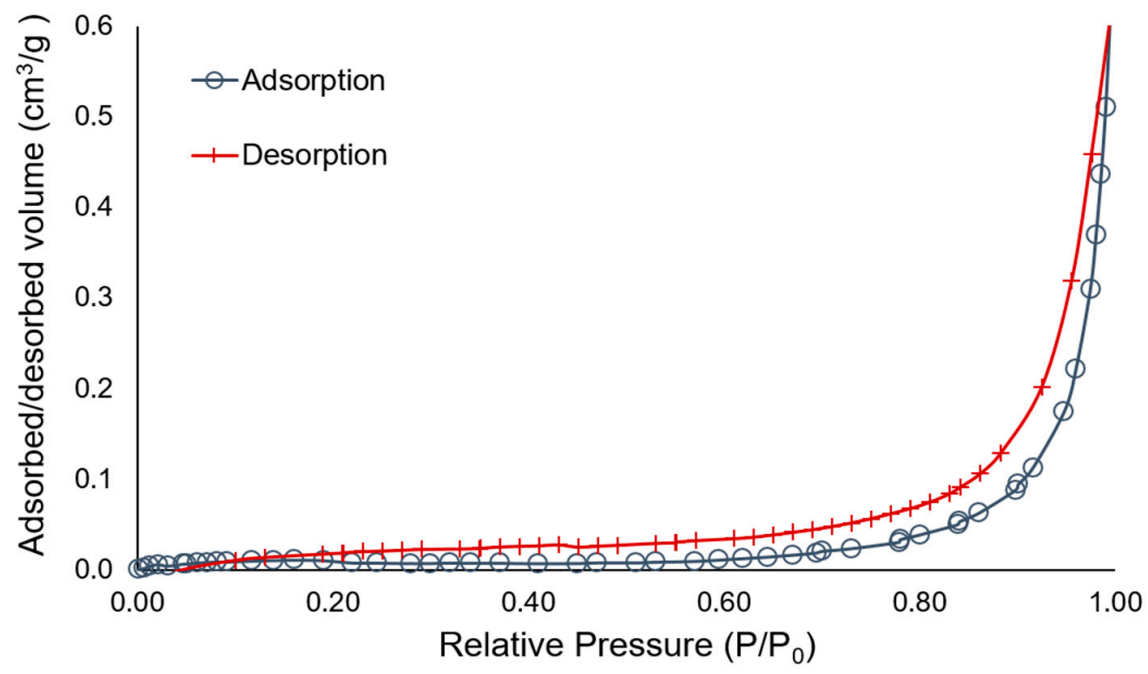

Figure 1. Nitrogen adsorption-desorption isotherms for coffee waste from $A$ company depending on the relative pressure.

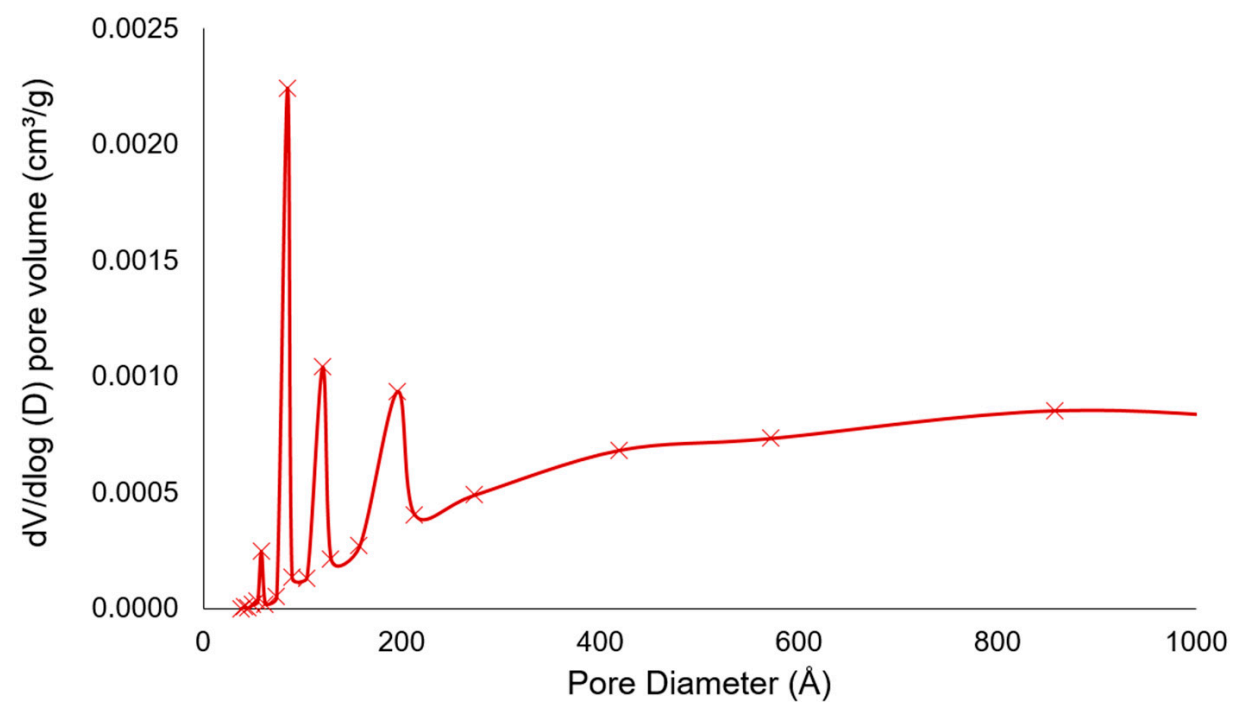

Figure 2. $\mathrm{dV} / \mathrm{d} \log (D)$ pore volume of coffee waste from $A$ company according to the pore size distribution.

\subsection{Absorption Properties}

To investigate the absorption capacity of coffee wastes for the extraction of arsenic element from wastewater, a series of different experimental conditions such as concentration of arsenic and amount of coffee waste were applied.

As shown in Figure 3, absorption property measurements for the coffee waste were conducted at different concentrations of arsenic ranging from $0.25 \mathrm{mM}$ to $1.00 \mathrm{mM}$ in wastewater. It was demonstrated that the concentration of absorbed arsenic from wastewater was increased proportionally to the concentration of arsenic in both companies, which was due to the fact that increased initial concentration of arsenic provided more sources to be absorbed in a given time. The maximum absorption concentration was $161 \mathrm{ppm}$ at $1.00 \mathrm{mM}$ in the $A$ company. In addition, the absorption capacity of coffee waste from $A$ company was superior to that of $B$ company, which might be due to the slightly different chemical structures constituting the coffee beans from different origins. 


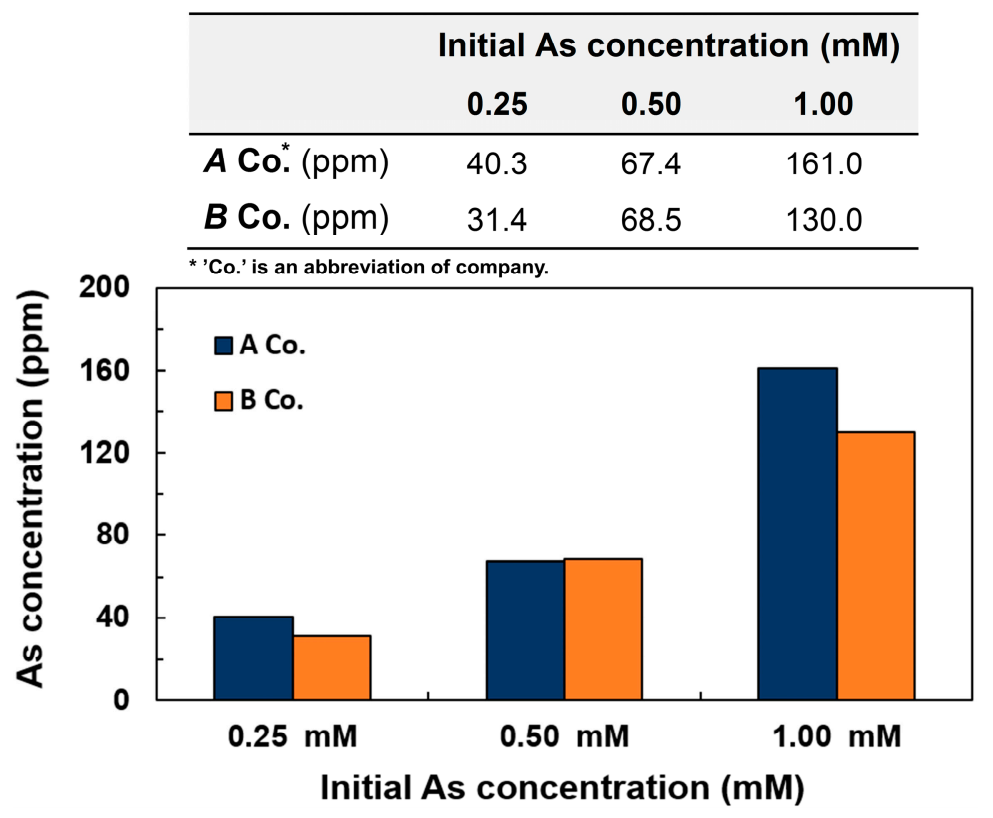

Figure 3. Concentration of arsenic absorbed on $25 \mathrm{~g}$ of coffee waste from wastewater depending on initial arsenic concentration at $\mathrm{pH} 7$.

In addition, different amounts of coffee wastes from $25 \mathrm{~g}$ to $100 \mathrm{~g}$ were used to see how the absorption capacities of arsenic from the wastewater would be changed according to the amount of coffee grounds. As shown in Figure 4, the amount of arsenic absorbed on the coffee waste increased proportional to amount of coffee waste, which was due to the increased surface areas of the coffee waste to react with arsenic element in the wastewater, where the maximum concentration of $94.2 \mathrm{ppm}$ was observed at $100 \mathrm{~g}$ of coffee waste on $A$ company. Quite a small concentration of absorbed arsenic was observed on $100 \mathrm{~g}$ of coffee waste from a $B$ company, which seemed to be an experimental error. Since this research is just a preliminary test to see if the coffee waste can absorb arsenic from the water, we did not do the experiments repeatedly, and the result can be expected based on the adsorption tendency.

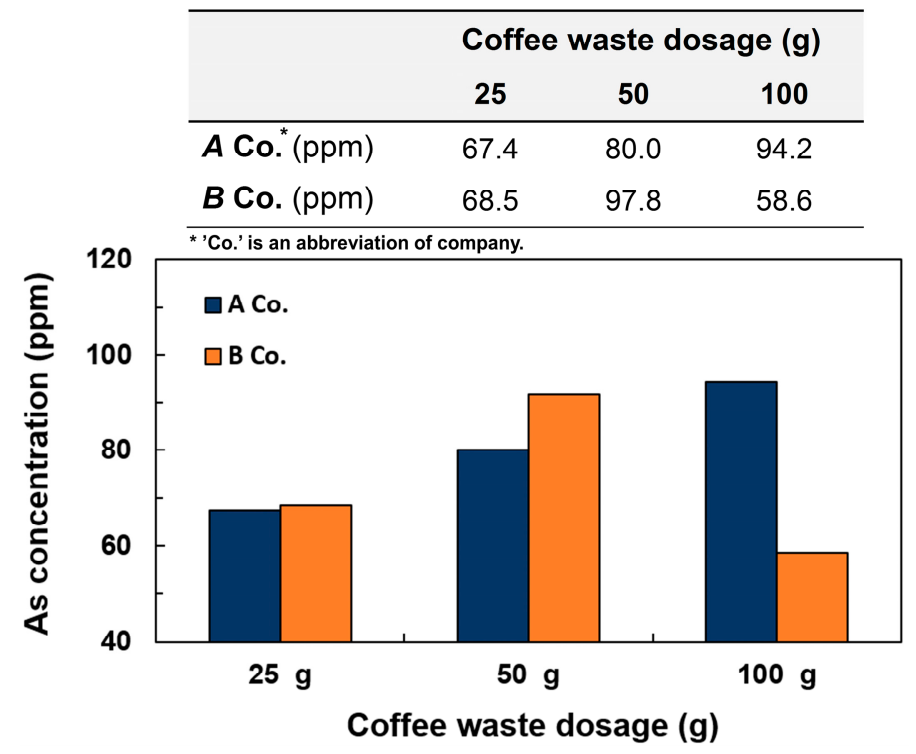

Figure 4. Arsenic concentration from $0.5 \mathrm{mM}$ of arsenic wastewater on different coffee waste dosages at $\mathrm{pH} 7$. 
Furthermore, to investigate the change of absorption capacity of the coffee waste at different $\mathrm{pHs}$, $25 \mathrm{~g}$ of coffee waste was added into $0.50 \mathrm{mM}$ of three arsenic wastewater with $\mathrm{pH} 4,7$, and 10 . As shown in Figure 5, it was demonstrated that the acidic and basic condition resulted in better absorption capacity compared with the neutral $\mathrm{pH}$ condition. Generally, As (III) and As (V) exist as various morphic compounds in the solution according to the different $\mathrm{pH}$ condition. In the case of As (V) used in this research, as shown in Equations (1)-(3), As (V) exists in the solution as a function of different $\mathrm{pH}$ [36]. Therefore, different kinds of arsenic species can induce the different reaction activity with coffee waste.

$$
\begin{aligned}
\mathrm{H}_{3} \mathrm{AsO}_{4} & \leftrightarrow \mathrm{H}^{+}+\mathrm{H}_{2} \mathrm{AsO}_{4}{ }^{-} ; \mathrm{pK} 1=2.3 \\
\mathrm{H}_{2} \mathrm{AsO}_{4}{ }^{-} & \leftrightarrow \mathrm{H}^{+}+\mathrm{HAsO}_{4}{ }^{2-} ; \mathrm{pK} 2=6.8 \\
\mathrm{HAsO}_{4}{ }^{2-} & \leftrightarrow \mathrm{H}^{+}+\mathrm{AsO}_{4}{ }^{3-} ; \mathrm{pK} 3=11.6
\end{aligned}
$$

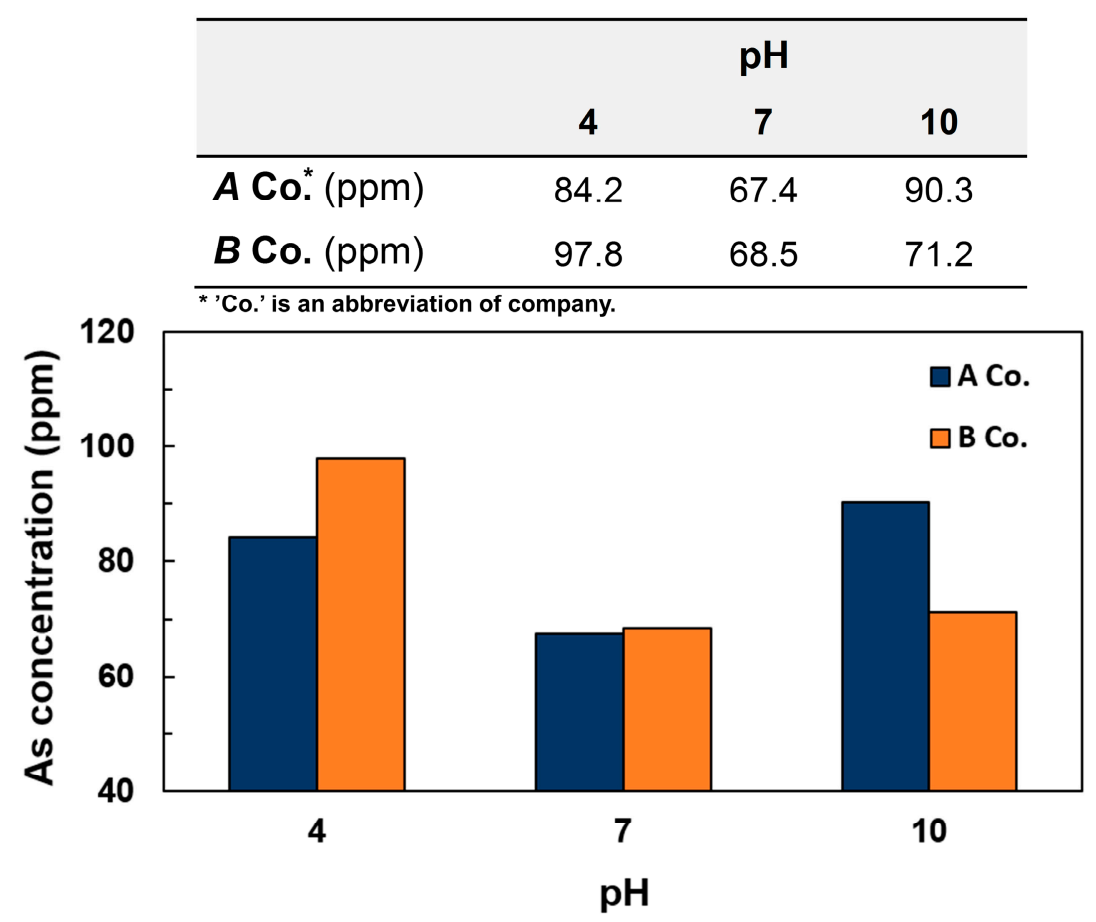

Figure 5. Concentration of arsenic on $25 \mathrm{~g}$ of coffee waste extracted from $0.5 \mathrm{mM}$ of arsenic wastewater depending on different $\mathrm{pH}$ conditions.

Even though the results of a series of experiments verified that the coffee grounds were helpful for extracting arsenic elements from wastewater, it was found that the observed absorption capacity was relatively low. In order to demonstrate the outstanding adsorption property as an absorbent, it is necessary for the absorbent to possess good physical as well as chemical adsorption capacities. In this study, arsenic exists as anions- such as $\mathrm{H}_{2} \mathrm{AsO}_{4}{ }^{-}, \mathrm{HAsO}_{4}{ }^{2-}$, and $\mathrm{AsO}_{4}{ }^{3-}$-at different $\mathrm{pH}$ conditions. To facilitate the adsorption by the chemical bonding with anions, the surface of the absorbent should be made up of the cationic charge. However, since the surfaces of coffee grounds consist of functional groups such as hydroxyl, amino, and carboxyl groups showing the anionic charge [26-28], arsenate ions cannot interact with the coffee waste due to the repulsive interaction. The amount of absorbed arsenic element in this study might arise from the results of physical adsorption. However, the reason that relatively low concentrations of arsenic were observed is due to the small surface area and volume of untreated coffee grounds. Therefore, pretreating the untreated coffee wastes such as calcination to eliminate the impurities and modification with other cation reagents would be necessary to improve the adsorption capacity of the coffee waste [30]. 


\section{Conclusions}

A series of experimental investigations for a removal of arsenic from wastewater have been conducted by an environmentally friendly method using renewable coffee wastes. As a consequence, preliminary tests for the removal of arsenic from wastewater using the untreated coffee grounds have shown that coffee waste is a possible material as an adsorbent for the extraction of arsenic. It was verified that the adsorption properties were enhanced as the added concentration of arsenic and quantity of coffee wastes were increased. In addition, better adsorption properties were observed in the acidic and basic environments than the neutral $\mathrm{pH}$ condition. The observed maximum absorption concentration of arsenic element on the $1 \mathrm{~g}$ of coffee grounds was $6.44 \mathrm{mg} / \mathrm{L}$ at $1.00 \mathrm{mM}$ of arsenic solution at $\mathrm{pH} 7$. The BET surface area was $0.0469 \mathrm{~m}^{2} / \mathrm{g}$, which was a quite low value as an absorbent, but adsorption pore distribution and adsorption-desorption isotherms indicated that the coffee grounds had a mesoporous structure, showing sufficient possibility as an absorbent. To enhance adsorption and for practical uses, a pretreatment process such as the calcination and modification with some chemical reagents is being pursued.

Acknowledgments: This work was supported by the Korea Institute of Energy Technology Evaluation and Planning (KETEP) and the Ministry of Trade, Industry \& Energy (MOTIE) of the Republic of Korea (No. 20141010101880).

Author Contributions: Ji Whan Ahn conceived of and designed the experiments. Gnu Nam, Min-Suk Kim, Namju Lee, and Young-Hoon Choi performed the all experimental procedures and measurements. Gnu Nam wrote the paper.

Conflicts of Interest: The authors declare no conflict of interest. The founding sponsors had no role in the design of the study; in the collection, analyses, or interpretation of data; in the writing of the manuscript; nor in the decision to publish the results.

\section{References}

1. Smith, V.H. Eutrophication of freshwater and coastal marine ecosystems-A global problem. Environ. Sci. Pollut. Res. 2003, 10, 126-139. [CrossRef]

2. Gleick, P.H. Global freshwater resources: Soft-path solutions for the 21st century. Science 2003, 302, 1524-1528. [CrossRef] [PubMed]

3. Flaten, T.P. Aluminium as a risk factor in Alzheimer's disease, with emphasis on drinking water. Brain Res. Bull. 2001, 55, 187-196. [CrossRef]

4. Arnell, N.W. Climate change and global water resources. Glob. Environ. Chang.-Hum. Policy Dimens. 1999, 9, S31-S49. [CrossRef]

5. Carriger, J.F.; Castro, J.; Rand, G.M. Screening historical water quality monitoring data for chemicals of potential ecological concern: Hazard assessment for selected inflow and outflow monitoring stations at the water conservation areas, South Florida. Water Air Soil Pollut. 2016, 227. [CrossRef]

6. Shakoor, M.B.; Nawaz, R.; Hussain, F.; Raza, M.; Ali, S.; Rizwan, M.; Oh, S.-E.; Ahmad, S. Human health implications, risk assessment and remediation of As-contaminated water: A critical review. Sci. Total Environ. 2017, 601-602, 756-769. [CrossRef] [PubMed]

7. Bosch, A.C.; O’Neill, B.; Sigge, G.O.; Kerwath, S.E.; Hoffman, L.C. Heavy metals in marine fish meat and consumer health: A review. J. Sci. Food Agric. 2016, 96, 32-48. [CrossRef] [PubMed]

8. Keil, D.E.; Berger-Ritchie, J.; McMillin, G.A. Testing for toxic elements: A focus on Arsenic, Cadmium, Lead, and Mercury. Lab. Med. 2011, 42, 735-742. [CrossRef]

9. Balakrishnan, H.; Velu, R. Eco-Friendly technologies for heavy metal remediation: Pragmatic approaches. In Environmental Sustainability: Role of Green Technologies; Springer: New Delhi, India, 2015; Volume 1, pp. 205-215.

10. Henke, K.R. Arsenic in natural environments. In Arsenic: Environmental Chemistry, Health Threats, and Waste Treatment; Henke, K.R., Ed.; John Wiley \& Sons: Hoboken, NJ, USA, 2009; pp. 69-236.

11. Garelick, H.; Jones, H.; Dybowska, A. Arsenic pollution sources. In Reviews of Environmental Contamination and Toxicology; Garelick, H., Jones, H., Eds.; Springer: New York, NY, USA, 2008; Volume 197, pp. $17-60$. 
12. Islam, M.S.; Ahmed, M.K.; Raknuzzaman, M.; Habibullah-Al-Mamun, M.; Islam, M.K. Heavy metal pollution in surface water and sediment: A preliminary assessment of an urban river in a developing country. Ecol. Indic. 2015, 48, 282-291. [CrossRef]

13. Carolin, C.F.; Kumar, P.S.; Saravanan, A.; Joshiba, G.J.; Naushad, M. Efficient techniques for the removal of toxic heavy metals from aquatic environment: A review. J. Environ. Chem. Eng. 2017, 5, 2787-2799. [CrossRef]

14. Hao, L.; Desai, M.K.; Wang, P.; Valiyaveettil, S. Successive extraction of As(V), Cu(II), and P(V) ions from water using surface modified ghee residue protein. ACS Sustain. Chem. Eng. 2017, 5, 3742-3750. [CrossRef]

15. Boonamnuayvitaya, V.; Chaiya, C.Y.; Tanthapanichakoon, W.; Jarudilokkul, S. Removal of heavy metals by adsorbent prepared from pyrolyzed coffee residues and clay. Sep. Purif. Technol. 2004, 35, 11-22. [CrossRef]

16. Babel, S.; Kurniawan, T.A. Low-cost adsorbents for heavy metals uptake from contaminated water: A review. J. Hazard Mater. 2003, B97, 219-243. [CrossRef]

17. Peng, Q.M.; Guo, J.X.; Zhang, Q.R.; Xiang, J.Y.; Liu, B.Z.; Zhou, A.G.; Liu, R.P.; Tian, Y.J. Unique lead adsorption behavior of activated hydroxyl group in two-dimensional titanium carbide. J. Am. Chem. Soc. 2014, 136, 4113-4116. [CrossRef] [PubMed]

18. Upadhyay, R.K.; Soin, N.; Roy, S.S. Role of graphene/metal oxide composites as photocatalysts, adsorbents and disinfectants in water treatment: A review. RSC Adv. 2014, 4, 3823-3851. [CrossRef]

19. Naushad, M.; Mittal, A.; Rathore, M.; Gupta, V. Ion-exchange kinetic studies for Cd(II), Co(II), Cu(II), and $\mathrm{Pb}$ (II) metal ions over a composite cation exchanger. Desalin. Water Treat. 2015, 54, 2883-2890. [CrossRef]

20. Bolisetty, S.; Mezzenga, R. Amyloid-carbon hybrid membranes for universal water purification. Nat. Nanotechnol. 2016, 11, 365-371. [CrossRef] [PubMed]

21. He, J.; Chen, J.P. A comprehensive review on biosorption of heavy metals by algal biomass: Materials, performances, chemistry, and modeling simulation tools. Bioresour. Technol. 2014, 160, 67-78. [CrossRef] [PubMed]

22. Boudrahem, F.; Soualah, A.; Aissani-Benissad, F. Pb(II) and Cd(II) removal from aqueous solutions using activated carbon developed from coffee residue activated with phosphoric acid and zinc chloride. J. Chem. Eng. Data 2011, 56, 1946-1955. [CrossRef]

23. Wu, C.H.; Kuo, C.Y.; Guan, S.S. Adsorption of heavy metals from aqueous solutions by waste coffee residues: Kinetics, equilibrium, and thermodynamics. Desalin. Water Treat. 2016, 57, 5056-5064. [CrossRef]

24. Kumar, K.S.; Dahms, H.U.; Won, E.J.; Lee, J.S.; Shin, K.H. Microalgae-A promising tool for heavy metal remediation. Ecotoxicol. Environ. Saf. 2015, 113, 329-352. [CrossRef] [PubMed]

25. Wang, J.; Chen, C. Biosorbents for heavy metals removal and their future. Biotechnol. Adv. 2009, 27, $195-226$. [CrossRef] [PubMed]

26. Nuruddin, M.; Hosur, M.; Uddin, M.J.; Baah, D.; Jeelani, S. A novel approach for extracting cellulose nanofibers from lignocellulosic biomass by ball milling combined with chemical treatment. J. Appl. Polym. Sci. 2016, 133, 42990. [CrossRef]

27. Wang, L.Y.; Wang, M.J. Removal of Heavy Metal Ions by Poly (vinyl alcohol) and Carboxymethyl Cellulose Composite Hydrogels Prepared by a Freeze-Thaw Method. ACS Sustain. Chem. Eng. 2016, 4, 2830-2837. [CrossRef]

28. Vardon, D.R.; Moser, B.R.; Zheng, W.; Witkin, K.; Evangelista, R.L.; Strathmann, T.J.; Rajagopalan, K.; Sharma, B.K. Complete utilization of spent coffee grounds to product biodiesel, bio-oil, and biochar. ACS Sustain. Chem. Eng. 2013, 1, 1286-1294. [CrossRef]

29. Azouaou, N.; Sadaoui, Z.; Djaafri, A.; Mokaddem, H. Adsorption of cadmium from aqueous solution onto untreated coffee grounds: Equilibrium, kinetics and thermodynamics. J. Hazard Mater. 2010, 184, 126-134. [CrossRef] [PubMed]

30. Chavan, A.A.; Pinto, J.; Liakos, I.; Bayer, I.S.; Lauciello, S.; Athanassiou, A.; Fragouli, D. Spent coffee bioelastomeric composite foams for the removal of $\mathrm{Pb}^{2+}$ and $\mathrm{Hg}^{2+}$ from water. ACS Sustain. Chem. Eng. 2016, 4, 5495-5502. [CrossRef]

31. Hao, L.; Wang, P.; Valiyaveettil, S. Successive extraction of $\mathrm{As}(\mathrm{V}), \mathrm{Cu}(\mathrm{II})$ and $\mathrm{P}(\mathrm{V})$ ions from water using spent coffee powder as renewable bioadsorbents. Sci. Rep. 2017, 7, 42881. [CrossRef] [PubMed]

32. Marincas, O.; Floare-Avram, V.; Feher, I.; Lazar, D.; Voica, C.; Grosu, I. Inexpensive adsorbents derived from coffee grounds for the treatment of wastewater. Anal. Lett. 2016, 49, 2659-2670. [CrossRef]

33. Guu, F.; Zhu, G.; Gao, B.; Zhang, D.; Tian, G.; Chen, Y.; Zhang, W.; Qiu, S. Adsorption of vitamin B12 on ordered mesoporous carbons coated with PMMA. Carbon 2005, 43, 2344-2351. [CrossRef] 
34. Ouyang, X.; Ouyang, J.; Guo, F. Development of a fuzzy analytical network process to evaluate alternatives on vitamin B12 adsorption from wastewater. Comput. Chem. Eng. 2016, 95, 123-129. [CrossRef]

35. AL Othman, Z.A. A review: Fundamental aspects of silicate mesoporous materials. Materials 2012, 5, 2874-2902. [CrossRef]

36. Wei, Z.; Liang, K.; Wu, Y.; Zou, Y.; Zuo, J.; Arriagada, D.C.; Pan, Z.; Hu, G. The effect of pH on the adsorption of arsenic(III) and arsenic(V) at the $\mathrm{TiO}_{2}$ anatase [101] surface. J. Colloid Interface Sci. 2016, 462, 252-259. [CrossRef] [PubMed]

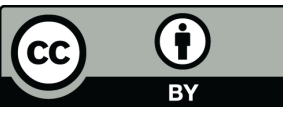

(C) 2017 by the authors. Licensee MDPI, Basel, Switzerland. This article is an open access article distributed under the terms and conditions of the Creative Commons Attribution (CC BY) license (http:/ / creativecommons.org/licenses/by/4.0/). 